\title{
Lovforslag mot kjønnssykdommer - frivillighet og «samfundsfiendtlige individer»
}

\author{
Norge fikk særegne lover for lepra i 1885 og for tuberkulose i 1900. Mange mente Norge måtte ha en egen \\ lov mot kjønnssykdommer også, og fra 1892 og fremover ble det gjort flere forsøk på å utarbeide lovforslag \\ som skulle regulere oppsporingen og behandlingen av kjønnssykdommer. Etter den første verdenskrig var \\ kjønnssykdommene for raskt oppadgående, og i Sverige vedtok man den såkalte Lex Veneris i 1918. Året \\ etter ble det satt ned en ny komité i Norge, som i 1923 leverte et nytt lovforslag som i stor grad bygde på det \\ svenske forbildet fra 1918. Gratis behandling og sykehusinnleggelse på statens regning for pasienter med \\ kjønnssykdom var viktige elementer i lovforslaget. Det ble lagt vekt på frivillighetsprinsippet, men det var \\ også et ris bak speilet: Tvangsbehandling skulle vente de pasienter som ikke «loyalt» fant seg i at forholds- \\ reglene og behandlingen ble gjennomført fullt ut. I denne artikkelen redegjør avdelingsoverlege ved hud- \\ avdelingen Edvin Bruusgaard (1869-1939) på Rikshospitalet for den foreslåtte loven (Tidsskr Nor Læge- \\ foren 1926; 46: 1075-85). Forslaget gikk imidlertid av ulike grunner ikke gjennom i denne omgang; Norge \\ fikk sin egen kjønnssykelov først i 1947.
}

\section{De forende linjer i kampen mot de veneriske sygdomer og det nye norske lovforslag om foranstaltninger mot kjønssygdommer.}

Av Edvin Bruusgaard.

Siden de epokegjørende opdagelser paa syfilidologiens omraade er der nu gaat saa mange aar hen, at vi selv hvor det gjælder en saa kronisk forløpende sygdom som syfilis med fuld ret har lov til at stille de spørsmaal: - Hvilke har de praktiske resultater været, som vi hittil har høstet av disse fremskridt, og hvordan skal de midler og metoder, som vi har i vor haand, bedst utnyttes i kampen mot denne sygdom, som i alle samfundsklasser foraarsaker en saa ødelæggende virkning?

[...] Den tidlig konstaterte infektion og den dertil knyttede behandling er hygienisk set vort hovedmiddel ved bekjæmpelsen av de veneriske sygdommer, og det er ogsaa i virkeligheten vort vigtigste profylaktikum. Konsekvensen herav maa være at søke at faa alle som er inficert til at søke læge saa hurtig som mulig. Hvordan $s \mathrm{k}$ a l det opnaaes? For det første maa folket i sin helhet oplyses om de veneriske sygdommer og deres betydning for individ og samfund. [...] Men opgaven er ikke let, der hører en særegen evne til at kunne fremstille medicinske spørsmål i en klar og letfattelig form, særlig vanskelig hvor det gjælder disse sygdommer, der kræves her meget finfølelse og takt; med skræmmende billeder, frygtindjagende hæslige moulager og kinematografforestillinger opnaaer man meget lite. [...] Da disse sygdommer meed sin store utbredelse er et samfundsonde av den aller største betydning, blir det staten som efter de moderne hygieniske principper maa løse denne opgave. Staten, eller stat og kommune i fællesskap, maa yde alle som ønsker det gratis behandling uanset deres økonomiske evne, samtidig som de faar sikkerhet for at fra det øieblik de har betrodd sig til lægen skal alt foregaa paa den mest diskrete maate, ingen skal nære frygt for at det kan gaa ut over ens person eller stilling. Patienten skal ogsaa, hvor det gjælder disse sygdommer, i lægen se sin raadgiver i hvis hænder han trygt kan betro sig. Det er kun en fordring, som staten da ikke alene har ret men ogsaa pligt til at stille; patienterne maa loyalt finde sig i at de forholdsregler som foreskrives og den behandling som kræves, gjennemføres helt ut. Hvis ikke det opfyldes, kan statens representanter med loven i haand sørge for at saa sker. [...] Nødvendigheten av at lægerne og sundhedsmyndigheterne kan gripe ind overfor patienter, som av uforstand, letsindighet eller ren vrangvilje avbryter behandlingen, er indlysende. Blandt disse findes farlige smittekilder, prostituerte, alkoholister, soutenører, som ofte tilsynelatende symptomfri gennem lang tid fører sygdommen videre, og særlig disse gjælder det at faa fat $\mathrm{i}$; en indlæggelise i sykehus vil da være paa sin plass. Det er en indskrænking i den personlige frihet; men det er samfundsfiendtlige individer, det sker derfor først og fremst i samfundets interesse, men ogsaa i patientens egen.

Jeg tror ikke man skal beskyldes for et forut indtat standpunkt, naar man søker den væsentlige aarsak til den misère vi befinder os i, i den mangel paa system hvorunder behandlingen av de veneriske sygdommer foregaar hertillands. Som overlæge ved hudavdelingen og leder av den ene av de to poliklinikker for disse sygdommer i Oslo har jeg daglig anledning til at se hvor litet tidsmæssig det hele er ordnet, hvor litet det tilfredsstiller de moderne krav. Hvad vi mangler er en særlov for disse sygdommer; uten en saadan vil bekjæmpelsen av kjønsgydommer fra et medicinsk-hygienisk standpunkt ikke kunne bli effektiv.

Bekjæmpelsen av kjønssygdommene er en av de vigtigste opgaver den sociale hygiene er stillet overfor, de er en statsfare hvis betydning fuldt ut kan sidestilles med tuberkulosens. 